\title{
Teacher Talk in Classroom Interaction: A Study at an English Department in Indonesia
}

\author{
Ryan Rayhana Sofyan \\ Murni Mahmud \\ English Department, Languages and Literature Faculty \\ of the State University of Makassar, Indonesia
}

\begin{abstract}
The research aims at analyzing teacher talk in classroom interaction based on Foreign Language Interaction Analysis (FLINT) system in speaking classroom of English department of Language and Literature Faculty of State University of Makassar. The method used in this research was a descriptive method. The instruments were FLINT system. The participants of the research were the lecturer and students of a speaking class during the second semester of academic year 2011/2012 at English Department of Language and Literature Faculty of State University of Makassar. The results of the research are: teacher talk of giving praises and encouragement is approximately less, the asking questions category dominate the teacher talk category, which means it is in the beneficial function. The lecturer asked the questions to the students and the students responded it well by speaking eagerly. The utterances of giving direction occurred in relatively short times. While in student talk, there are students' problems and difficulties in speaking. The extracts of student talk in classroom interaction revealed the students problems such as the lack of vocabulary, anxiety, inability to form ideas in English language form, and grammar error. The teacher talk frequency was still excessive, but the lecturer made group and pair discussions to balance the effective talk for students in student-student interaction.
\end{abstract}

Keywords: Classroom, interaction, FLINT, Speaking

\section{INTRODUCTION}

Learning a language is not only to develop the learners' intelligence, but also to keep social interaction and emotion. In teaching a language, the main goal is to develop the learners' communicative competence. Communicative competence is ability to create discourse. Interaction may seem as a simple 


\section{6 | ELT Worldwide Vol. 1 No. 1}

thing to do, but there are many obstacles in building a good interaction in order to help students developing their speaking skill. Menegale (2008) found in her research that teachers still dominate the talking time in the class. It is the most common and conventional custom that happen inside the classroom in the middle of teaching and learning process. This research is in accordance to the research finding of Jae-Hwang (2010) that in the classroom interaction, teacher talk dominates most of the teaching and learning process in the classroom. The analysis showed that the elicitation, response and feedback was taken over and used systematically by teacher. So the students did not have appropriate time and opportunity in expressing their thoughts and exploring their ideas.

The research was intended to examine teacher talk at the Speaking Class at the English Department, Language and Literature Faculty of State University of Makassar. It is hoped that the findings of this research may be used to improve the effectiveness of the class.

\section{LITERATURE REVIEW}

\section{Definition of interaction}

Brown (2007) defined interaction as collaborative exchange of thoughts, feeling, or ideas between two or more people, resulting in a reciprocal effect on each other. The theories of communicative competence accentuate the role of language use in various context to negotiate meaning in human life. In other words, to get the idea from someone's mind into others' mind and vice versa.

From the definitions above, I may conclude that interaction is a verbal or non-verbal relation to communicate meaning between one person to another or one person to group of people and vice versa or among groups of people. Interaction can take place in many social context such as business meeting, leisure gathering, sport and arts activities and educational events. Here, interaction will be focused on interaction in the classroom that involves teacher and students in verbal and nonverbal relation.

\section{Teacher Talk in Foreign Language Interaction (FLINT) System}

The following are the teacher talk categories as described by Brown (2007).

\section{Deals with feeling}

In dealing with students feeling, it is also important to communicate students past feeling. It is important because their experiences shaped their minds, the reason behind their feeling in present time, and it helps teacher avoiding students' trauma. The understanding from teacher and the right way of 
handling with students feeling will comfort the teacher-students interaction in the classroom.

\section{Praises and encourages}

Teacher activities are not only conducting lesson plan and develop teaching material but also motivate students to raise their motivation so they can find and develop their language skill. Motivation for students must be done as well so the objectives of the lesson are achieved like the way it planned. In doing their daily activities in the classroom, teacher can support students with praising, complimenting and tell the students that their ideas and works are valuable. Students may feel stuck or blank in the middle of their speaking performance.

\section{Uses ideas of students}

Teacher's attention to students' contribution is a great appreciation for students' works. Some ways in expressing the appreciation, such clarify, using, interpret or summarize the ideas of students. Teacher can start a discussion based on students' ideas by rephrasing them but still recognized as students' contribution.

\section{Asks questions}

As it brought before in previous pages, questioning in interaction is a way to stimulate students speaking up their thoughts. There are many ways to classify the kinds of questions for classroom effectiveness. The questions can be categorized by the level of the students. Teacher usually begins with display questions which the answers is common knowledge. The display questions can be used to provokethe contain of students ideas and their language form.

\section{Gives information}

Giving information is a classic teaching method where teacher gives information, facts, personal opinion, or ideas about a topic. It is simply gives students the lecture or asking rhetorical questions. Nowadays, this method is considered as out-of-date method for teaching and learning process because students should be active in the classroom. To avoid this kind of method, it does not mean that the teacher leave the whole classroom activities to the students. Teacher should conduct lesson plan and develop material so he/she can stimulate students' behavior.

\section{Gives directions}




\section{8 | ELT Worldwide Vol. 1 No. 1}

There are many activities can be developed in speaking class for classroom interaction. Students have good opportunity to explore their ideas. Students need some direction and facilitation of information on how they should demonstrate the whole ideas they own systematically. They expect some direction or command from their teacher. So teacher should direct the various exercises and facilitate them by giving a whole-class or small-group activities.

\section{Criticize student behavior}

Sometimes in the classroom,there are a few students that are difficult to handle. In students' age, there are many internal problems they should face, such as puberty and unstable emotion. This is when teacher should communicate anger and so dissatisfaction and annoyance with students.

Teacher should know the way to communicate the emotion atmosphere in the classroom so teacher can find a solution to solve the problem and build a positive interaction with students. Teacher's critics is important for students' leadership development. Telling the students about incorrect or acceptable response must be done in positive behavior without letting down the students' passion in learning.

\section{Related Research Findings}

There are many researchers who have spent their effort in observing discourse analysis in classroom interaction. Some researchers have conducted research relating to discourse analysis in classroom interaction. They are cited below:

1. In Zambrano (2003), the fact from the research expose the cliché problems in classroom interaction that the teacher talked a great deal. While students who are suppose to actively speak only had a little time and opportunity to speak. Hence, the speaking class were not run appropriately.

2. Hadef (2010) in her research used the 'dealing with peer interaction' as a new method in English teaching. This method help students speaking English like native speaker. Hadef stated that peer interaction is a way for students to acquire and develop their English language. Students can practice the language in their real context through interaction with each other. The students from her research also agree that this method plays important role in increasing their motivation which leads them gaining improvement in speaking skill. 
Based on the previous research findings above, I may conclude that interaction in the classroom, which is performed by teacher and students holds important role in teaching and learning process. Besides that, there are still many issues and problems emerge in classroom interaction.

\section{METHOD}

In this part, the researcher explains the research design, research participants, research focus, research instruments, research data, data collecting procedures, and data analysis technique.

This research is a case study to analyze the classroom interaction in speaking class at the English Department of Language and Literature Faculty of State University of Makassar. The classroom interaction is genuine one as it is specifically intended for teaching purpose, not for the purpose of facilitating research. In analyzing the classroom interaction, the researcher employs qualitative method in order to answer the research question formulated in the problem statement. As qualitative method, it neither threats the subject nor manipulate the data taken from the sample, because its main purpose is to find out the reality in teacher-students interaction in the classroom based on the FLINT analysis system.

The participants of this research are the lecturer and students of speaking class registered at second semester of academic year 2011/2012 at English Department of Language and Literature Faculty of State University of Makassar. There are four classes registered on English Education Study Program, namely Class A, B, C and D. The classes are taught by the same lecturer. Since the classes are relativelyhomogene, the researcher randomly selected one class to be studied. The selected class is class B. The class consisted of 35 students. The researcher have observed 6 class sessions by considering that the amount of observation is enough to portray the classroom interaction.

\section{RESULTS}

Based on the overview from the six meetings of classroom interaction, it shows that most of the time in each classroom meeting were dominated by teacher talk.

\section{Dealing with feelings}

This first category in FLINT system includes the discussion, acceptance, referring to and communicating the students feeling in past, present and/or 
50 | ELT Worldwide Vol. 1 No. 1

future time. As we can see, the classroom discussion depended on the material the class were having.

\section{Extract 1}

T: Hah, really? Aha, and then what did you say?

S: And then eh..I say I'm sorry but he didn't really believe me and leave me.

T: $\quad$ Did he also say sorry to you?

S: Yes?

T: Did he say apologize to you?

S: He didn't apologize to me. Eh..he walk away.

The extract shows the discussion between the lecturer and one of the students about misunderstanding between the student and his best friend. The sentences in the extract like "I say I'm sorry but he didn't really believe me and leave me" and "He didn't apologize to me. Eh..he walk away" were the way of student told his story. He said that his best friend did not want to accept his apologize, did not trust him anymore and leave. The lecturer did the discussion and tried to reveal about the story by asking questions. The questions showed that the lecturer was curious about the story and the lecturer's attitude make the student felt accepted and comfortable to tell what was really happened between him and his best friend.

\section{Praises and encourages}

This part of category included the teacher talk of praising, implementing, encouraging students to continue, trying to give them confidence or confirming that the answers were correct. There is also a sub-category in this category which is jokes that attempted to be humorous that was done by the teacher.

Some extracts below shows the conversation where the lecturer gave praises and encouragement to the students.

\section{Extract 2}

T: You should tell that. That's a wonderful story. How about you?

S: yes..apa?

T: Your story.

$S: \quad[\ldots]$

T: [...] So, have you chosen two stories?

S: yes.

T: $\quad$ Okay, two stories.

Extract 2 shows the conversation which is taken from the first meeting. The lecturer went around the class when the group discussion was held. The lecturer listened about the student's story and praised her story by saying "You should tell that. That's a wonderful story." The student asked what 
was that about because she did not know that the lecturer listened to her story.

\section{Extract 3}

I: menurutta, bagaimana dengan memberikan pujian dan dorongan atau support dalam mengajar?

(In your opinion, how is the praise and encouragement role in teaching?)

T: iya, jelas sangat berpengaruh. Secara keseluruhan Saya memberikan nilai biasanya pada akhir pertemuan dan juga pada awal pertemuan, saya mengatakan pada mereka bahwa mereka harus memiliki kepercayaan diri dan tidak perlu merasa takut atau hal positif untuk mendukung mereka dalam berbicara bahasa Inggris.

(Of course, it has effects. Generally, I support them in the beginning of the meeting. I told them that they should have confidence and should not be afraid or any positive support for encouragement in speaking)

The data collection in extract 3 is taken from the interview with the lecturer about the classroom interaction shows that the lecturer rarely gave the praise and encouragement. The lecturer clarified it in the interview by saying "Saya mengatakan pada mereka bahwa mereka harus memiliki kepercayaan diri dan tidak perlu merasa takut atau hal positif untuk mendukung mereka dalam berbicara bahasa Inggris." (Of course, it has effects. Generally, I support them in the beginning of the meeting. I told them that they should have confidence and should not be afraid or any positive support for encouragement in speaking). The lecturer's utterance from the extract above implies that the encouragement is good motivation for students so they feel free in speaking English and praise them by giving the appreciation in the end of each meeting that they have done very.

\section{Using ideas of students}

Using ideas of students in this part of category appeared in every observed meeting. In this category, there are four elements we are going to discuss in using ideas of students, namely clarifying, interpreting, summarizing and rephrasing of what the students talk about.

\section{Extract 4}

S: Sinetron gives bad effects to young children. I eh [...] with that statement. You know that, when you are watching TV, the sinetron can watch for the children eh like simbol $B, R=$ remaja, $O=$ orang tua. So, when the young children watch eh sinetron for old the old people, it is give bad effect for young children.

T: So, do you agree with the solution that your group proposed just now that to limit the time for children to watch?

$S:$ [nodding] 
The conversation in extract 4 shows the clarification made by the lecturer based on the student explanation about his argument. After listening to the student's explanation, the lecturer clarified the idea by saying "So, do you agree with the solution that your group proposed just now that to limit the time for children to watch?" and then the student were nodding to justify the statement. The example of clarifying the ideas of students is taken from the extract of second meeting.

\section{Asking questions}

From the whole classroom meeting, asking question took the most frequent utterance that the lecturer said. Whether it was to stimulate the students to talk, to get students opinion or even though to get information from the students. The extracts below shows the questions asked by the lecturer for students to stimulate ideas in the students' speech.

\section{Extract 5}

T: Okay, and then we say regret and you also know how to accept the apology. Okay, "that's alright", "that's okay", "never mind". Okay, and also when you get shocked or surprise of something happen or serious incident. Okay, now, what you have to do with the member of..the members of your group, okay, each member tells each other about your condition when you have to say sorry, okay? Try to remember something happened to you, probably, last night, or a few weeks ago, or a few days ago, or even a few years ago. Okay, something happen that you have to say so sorry or probably you have to accept someone's apology. Okay, so each person in the group tells each other about your story, your experience about so sorry. Do you get what I mean?

In extract 5, whichis taken from the first meeting, the lecturer gave direction to the students in doing the activity that day. She explained about the material and the procedure of the activity of telling story that expressed sorry feeling. After explaining and directing the students, the lecturer asked the procedural question: "Do you get what I mean?" The question supported classroom management and routines that was different from those concerning the content of learning.

\section{Giving information}

The frequency in each meeting were varied and not too many times, but mostly each talking was longer take more time than the other. The extracts below shows us the lecturer's utterance in giving information to the students.

\section{Extract 6}

T: I'm sorry to hear about that. Or? 
Ss: [talking together]

T: Oh, that's too bad. I am sorry to hear it. Next, when you want to express regret about a minor accident or event. What will you say?

Ss: [talking together]

T: $\quad$ what a shame. Oh, that's too bad. Or, that's a shame. Okay, next page. When we got shocked or surprised of someone's serious incident. We say: "what?!" or "How awful", "how terrible", "how horrible".

In the extract, the utterance that was done by the lecturer, we can see the lecturer delivered discourse described about the topic or material on that day. In order to get the students understand the direction, there were several repetitions about the information in one meeting, like "Oh, that's too bad. I am sorry to hear it. Next, when you want to express regret about a minor accident or event."

\section{Giving direction}

Among the whole interaction in the class, giving direction was the clear category that the lecturer perform to make a classroom activity. Eventhough the sentences was unclear, it was usually given with gesture.

\section{Extract 7}

T: $\quad$ Okay, so that's the way of eh.. "How to describe people". Okay, first, what are the habits or what are the characteristic of the person that she mentioned? She is calm.

Ss: $\quad$ Calm, smart, like music, like mickey, mickey mouse, polite, sometimes come late to the class.

T: Any other things?

Ss: Beautiful. eeh, use Honda Beat.

The extract above is taken from the second meeting. In giving direction, besides using the imperative sentences, the lecturer also used interrogative sentences to make the students speak up their ideas by saying "Okay, first, what are the habits or what are the characteristic of the person that she mentioned?" and added the answer by saying "Any other things?". Because directing students to speak cannot only be done by telling them to but also by asking questions. In fact, by asking questions, the students felt more liberate to express their ideas.

\section{Criticizingstudents'behaviour}

The data collection shows there were 6 times utterances in the first meeting that indicated criticism. In the second meeting was 4 times, the third meeting was 5 times, the fourth meeting was 8 times, the fifth meeting was 8 times and the sixth meeting was only once. In criticizing student behavior, most of the lecturer's utterances were intended to manage the classroom, to 


\section{4 | ELT Worldwide Vol. 1 No. 1}

keep the students paying attention and listening to the speaker at that time. The example of criticizingstudents' behavior in the extract taken from the first meeting:

\section{Extract 8}

S: [confused] [talking together]

T: $\quad$ Explain please.

S: $\quad$ baca? (read)?

T: $\quad$ No, explain my direction just now. Do you understand?

S: [shaking head]

T: $\quad$ So what's your question? Do you have any question? What is that you don't understand?

S: $\quad$ Understand, mam.

T: $\quad$ Okay, explain to me my direction.

S: $\quad$ Oh..mmm.. eh.. I read my..

T: $\quad$ You pair up..

S: $\quad$ You pair up, and I read to my.

T: $\quad$ Not read. Explain.

S: $\quad$ Explain to my friend and he ask to me about what is he want to know to my explaining about..

T: $\quad$ And then?

S: $\quad$ And then..the second round..

T: $\quad$ No.that you don't get. Your friend will retell or explain to me what is it that you love the most. And after that, I will ask him questions. So, your partner should know everything about the things or people that you love the most. Do you understand? Okay?

The extract 8 above that is taken from the fifth meeting shows that the discussion was stimulated by students' misunderstanding of lecturer's direction. The lecturer criticized students' behavior by discussing the student misunderstanding. The lecturer said, "No, explain my direction just now. Do you understand?" and "So what's your question? Do you have any question? What is that you don't understand?" The lecturer asked the student to explain about the procedure and when she found the mistake, she corrected the mistake to avoid the misunderstanding by saying "No..that you don't get. Your friend will retell or explain to me what is it that you love the most. And after that, I will ask him questions. So, your partner should know everything about the things or people that you love the most. Do you understand? Okay?"

\section{DISCUSSION}

This section presents the discussion of the result of the data collection. It is aimed at describing the classroom interaction between lecturer and students based on FLINT system analysis. In this part, the categories are divided into 
three parts; they are teacher talk, student talk and other FLINT categories. There are also sub-categories that portrayed the whole classroom interaction. The words and actions of lecturer can act as encouragement when the focus is on the students and the process of learning, or they can act as praise when the focus of lecturer attention for outcome of learning. The distinction between praise and encouragement is important. Praise from the teacher means that the students have learnt well and it is a very motivate attitude for them to know that their work are being valued. While encouragement help the students with low achievement to learn (Brown, 2007).

The role of praise and encouragement in motivating students to learn is crucial as Thomas in Burnett (2002) referred praise as the positive reinforcement to stimulate desirable behavior. He also suggested that praise could be motivational tool in not only classroom interaction but also teacherstudents relation by describing behavior or assignment that merits the praise, mentioning student's name, and choosing the praise word carefully.

Using ideas of students in classroom discussion is one way of encouragement for students to be confident and to show them that their ideas are valuable. In most meetings that I have observed, the lecturer clarified and repeated the response verbatim. There are several items in using ideas of student such as clarifying, interpreting, and summarizing students' ideas. In extract 4 , using ideas of students' category shows the clarification made by the lecturer based on the student explanation about his argument. After listening to the student's explanation, the lecturer clarified the idea. This show the lecturer appreciation of the students' ideas and tried to custom the students to listen to the better sentence. As it is clarified by ENC (1995) that teacher can help students to gain their intellectual identity by respecting their ideas and encourage their independent thinking.

In asking questions category, we found the three types of questions. The extract 1 in asking questions category shows the procedural question that supported classroom management and routines that was different from those concerning the content of learning. The fact that asking questions in classroom interaction dominate the teacher talk is very positive as Cotton (1983; 3), stated that instruction which include posing questions during lessons is more effective in producing achievement gains than instruction carried out without questioning students... oral questions posed during classroom recitations are more effective in fostering learning than are written questions.

The next three categories of FLINT system considered as a direct influence in classroom interaction. Giving information to the students refers to the lecturer explanation about any information that should be delivered to the 


\section{6 | ELT Worldwide Vol. 1 No. 1}

students in classroom in the teaching and learning process. Giving information involves giving the students information, facts, lecturer's own opinion, lecture and rhetorical questions.

By giving direction, the lecturer can give the students a good opportunity to practice their English language by giving them direction to do the activities. To make them practice effectively, the lecturer should put an effort in giving explanation and clear instruction so they can maintain the attention in classroom activity. This category involves request and command that students are expected to follow, directing drills and facilitate the activity. In the extract 7 in giving direction category, we can see the direction was given with interrogative sentences. Besides the imperative sentence to direct and command to the students, there were several request made by interrogative sentence to confirm an activity.

Criticizing students' behavior is a natural and common thing that happened in teaching process. Extract 8 of criticizing students' behavior, the lecturer used more intonations in the utterances rather than teacher in school because the university students are maturer than the school students. Teacher utterances, attitude and tone in criticizing student behavior refers to communicating anger, displeasure, annoyance, rejection and dissatisfaction with students' attitude. The effort that teacher can do are like rejecting or try to change the non-acceptable behavior.

\section{CONCLUSION}

Teacher talk in classroom interaction of speaking class at English Department of Language and literature Faculty of State University of Makassar consists of dealing with feeling, praise and encouragement, using the ideas of students, asking questions, giving information giving direction and criticizing students' behavior. Teacher talk mostly appeared in giving direction and information, while in discussion the student took most of the time talking. It seems that the categories such dealing with feeling, praise and encouragement, using ideas of students, and asking questions are used by the lecturer to motivate and stimulate the students so they have opportunities to express their ideas. In fact, the positive ways of the lecturer delivered her ideas to the students stimulated the students' active learning. In active learning, according to Unesco $(2006 ; 32)$ "there is less emphasis on transmitting information from the teacher to the student (such as through lecturing) and freater emphasis on developing students' analytical and critical thinking skills, as well as on exploring attitudes and values held about course material".

One of the categories in teacher talk, namely dealing with students feeling is not described clearly in FLINT system. In the data collection, the researcher 
could get transcription of dialog of discussing students feeling because it was done as the topic of the discussion material. In my opinion, dealing with student feeling that is described in FLINT system is not appropriate to be discussed in classroom interaction. The discussion of students' personal feeling in anytime and how it affect students' learning is a personal matter that need more understanding of the teacher.

\section{Suggestion}

Related to the conclusion above, the researcher formulates some suggestions as the following points:

1. The categories FLINT systems are very helpful to describe the classroom interaction pattern. Even though dealing with student feeling category need more consideration.

2. The lecturer should give more praises and encouragement to the students to stimulate their speaking enthusiasm and build their selfconfidence in speaking up their thoughts.

3. In giving direction, there were several times when the lecturer repeated the procedure of the activity to the students. In order to make the students understand about the task, the lecturer should communicate by asking the students to repeat and re-explain about the lecturer direction. This way, the lecturer can not only find the misunderstanding and solve it, but also give the students more time and a good opportunity to speak up and evaluate the students understanding.

4. The lecturer should put more effort to encourage the students to practice more outside the classroom. Building a good relation outside the classroom among the students can result a positive impact in students self-confidence development. The lecturer should recognize the matters that interest the students and find relation in improving students speaking skill and then involve in those matters to participate contiguously.

5. The lecturer should initiate discussion concerning students' problems and difficulties in speaking. By knowing students problems and difficulties, the lecturer and students can focus to solve those problems in the classroom and evaluate at the end of each meeting. This communication helps the students to become aware of their lackness and by knowing it, the lecturer and students can find the solution to improve students speaking skills. 
58 | ELT Worldwide Vol. 1 No. 1

\section{REFERENCES}

Alderman, R. (2008). Faculty and Student Out-of-Classroom Interaction: Student Perceptions of Quality of Interaction. Texas A\&M University.

Brophy, J., Alleman, J.\&Knighton, B. (2010). A Learning Community in the Primary Classroom. New York: Routledge.

Brown, D. (2007). Teaching by Principles. San Fransisco State University. United State of America: Pearson Longman.

Cohen, L., Manion, L.\& Morrison, K. (2004). A Guide to Teaching Practice. New York: Routledge.

ENC. (1995). Constructing Knowledge in the Classroom. Southwest Consortium for the Improvement of Mathematics and Science Teaching. Winter, Volume 1, Number 3. Classroom Compass.

Hadef, R. (2010). Teaching Speaking through Peer Interaction. University Mentouri- Constantine. People's Democratic Republic of Algeria.

Mahmud, M. (2010). Politeness in Bugis (A Study in Linguistic Anthropology) Volume II. Makassar: BadanPenerbitUniversitasNegeri Makassar.

Menegale, M. (2008). Expanding Teacher-Student Interaction through More Effective Classroom Questions: From Traditional Teacher-Fronted Lessons to Student-Centred Lessons in CLIL. Italy: Ca' Foscari University of Venice.

Unesco. (2006). Practical Tips for Teaching Large Classes: A Teacher's Guide. Bangkok: Asia and Pasific Regional Bureaufor Education.

Zambrano, G. (2003). Teacher Talk at Three Colombian Higher Education Institutions. Universidad Ricardo Palma. 